\title{
Women in Transnational Migrant Activism: Supporting Social Justice Claims of Homeland Political Organizations
}

\author{
LIZA MUGGE \\ University of Amsterdam, Netherlands
}

\begin{abstract}
This article studies the conceptions of social justice of women active in transnational migrant politics over a period of roughly 20 years in the Netherlands. The novel focus on migrant women reveals that transnational politics is almost completely male dominated and directed. Two of the exceptions found in this article include a leftist and a Kurdish women's organization supporting the communist cause in the 1980s and the Kurdish struggle in the 1990s in Turkey, respectively. In both organizations, gender equality was subordinated to broader ideologies of political parties in their homeland. Leftist activists in the Cold War era supported a narrow definition of the "politics of redistribution," while Kurdish activists, combined classical features of the latter with those of traditional identity politics.
\end{abstract}

\section{Introduction}

Since the fall of the Berlin wall in 1989, the demise of communism and the continuing ascendance of free-market ideology, claims for social justice have shifted from redistributive issues to the "politics of recognition" (Fraser, 1996, pp. 3). While the first type of social justice claims seeks a more just distribution of resources and goods, the goal of the second type is a difference-friendly world. In the latter view, "assimilation to majority or dominant cultural norms is no longer the price of equal respect" (1996, pp. 3). Examples include claims for the recognition of ethnic minorities and gender differences. Globalization has increased the potential of such identity politics to become transnational. While there has been ample attention given to the transnationalization of women's activism and women's claims for equalityboth distributive and difference-friendly (Naples \& Desai, 2002) — as well as to migrant transnationalism (Vertovec, 2009), little research has focused on transnational claims of migrant women. 
This article examines how Turkish and Kurdish migrant women in the Netherlands had and have been involved in transnationalism before and after the fall of the Berlin wall. Which conceptions of social justice do they advocate? In what forms of transnational activism are they involved and to what extent are they influenced by factors related to organizations and politics in the country of origin? The next section points to the absence of gender in the literature on diaspora, transnational, and migrant politics. It is followed by a contextual section on the migration process of Turks and Kurds to the Netherlands and the development of the transnational organizational political infrastructure there. In particular, it shows that transnational politics is almost completely male dominated and directed. Subsequently, I present the only two exceptions to such male domination in my sample: one leftist and one Kurdish women's organization, supporting the communist struggle in the 1980s and Kurdish resistance in the 1990s in Turkey, respectively. The analysis confirms a shift in social justice claims after the demise of communism, in line with Fraser's argument. Intriguingly, however, although both organizations work with and for women, gender equality is subordinate to the political paradigms of Marxism and ethnic nationalism adhered to by the political parties they sympathize with.

\section{Gender: A Lacuna of Diaspora, Transnational and Migrant Politics Scholarship}

Despite a widespread scholarly agreement that gender matters in all social, economic and political spheres, research addressing gender outside typically "female" spaces, like the household, are scarce (Al-Ali, 2002; Levitt \& Jaworsky, 2007, pp. 137-139; Mahler, 1998, pp. 82-87; Vertovec, 2009, pp. 64-66). For instance, in most recent "state of the art" and "taking stock" special journal issues and edited volumes on migrant transnationalism and diaspora, full contributions or chapters on gender are absent (e.g. Bauböck \& Faist, 2010; Ben-Rafael, Sternberg, Liwerant, \& Gorny, 2009; Fibbi \& D’Amato, 2008; Khagram \& Levitt, 2008; Martiniello \& Lafleur, 2008; Pries, 2008; Vertovec, 2009). Not surprisingly, gender goes unnoticed in empirical studies on diaspora and transnational migrant politics (Brand, 2006; Esman, 2009; Ögelman, 2003; Østergaard-Nielsen, 2003; Shain, 1999; Sheffer, 2003; for an exception see Aliefendioğlu, 2004). Confirming this pattern, gender is not considered in studies on migrants' political participation and their organizational networks in the receiving country (Schrover \& Vermeulen, 2005; Van Heelsum, 2002; Vermeulen, 2006; Yurdakul, 2009).

There are, however, good reasons to bring gender into the study of diaspora, transnational and migrant politics. Existing scholarship suggests that migrant men's and women's involvement in social networks and transnationalism take very different forms (De Tona \& Lentin, 2011; Fouron \& Glick Schiller, 2001; Hagan, 1998; Itzigsohn \& Giorguli-Saucedo, 2005, p. 896; Menjívar 2000, pp. 157-193). The general finding is that migrant men play a role in public, 
formal and institutionalized domestic networks of migrant organizations and the transnational ties these maintain with homeland-based actors. In contrast, women seem to play an important role in informal networks consisting of friends and family. In other words, migrant women do not (manage to) get out of the transnational "private sphere."

Transnational politics is about getting a transnational public role (Salih, 2007). It is the institutionalized and public nature of migrants' organizational and transnational ties, which exceed the levels of the private sphere and the individual, that structures transnational politics (Mügge, 2010). A gendered analysis of the institutional level, therefore, provides a first impression of the women's organizations or organizations directed by women that have a public role in transnational politics. Before proceeding to that step, however, the following section provides background information on the emigration process from Turkey to the Netherlands and the gendered nature of the migrant organizational landscape.

\section{Gendered Emigration and Migrant Organizations}

Migrants from Turkey are the largest non-Western migrant group in the Netherlands $\left(388,967\right.$ in 2011). ${ }^{1}$ As Kurds are not registered on the basis of ethnicity or self-identification but on the country of birth (of at least one of the parents), which in this case is Turkey, official numbers for the Netherlands do not exist. Their estimated number is 100,000 (Moors, Van den Reek Vermeulen, \& Siesling, 2009).

Significant migration from Turkey was concentrated between 1964 and 1974, facilitated by a labour agreement between the Dutch and Turkish governments. Labour migration predominantly included Turkish men, but when they opted for permanent stay in the Netherlands, their wives and children followed quickly. Already in 1972, half of the Turkish migrants were women (Schapendonk-Maas, 2000, p. 26). A similar pattern is observed in Germany (Aliefendioğlu, 2004), and as figure 1 shows, it still holds today. Kurds were underrepresented in the first wave of labour migration in the 1960s as recruitment took place mainly in western and central Turkey, where few Kurds lived. This changed in the early 1970s when labour was increasingly recruited from eastern Turkey (Van Bruinessen, 1999). Many Kurds arrived in the Netherlands after the 1980 coup in Turkey (Bakker, Vervloet, \& Gailly, 2002, pp. 162-167).

Compared to other migrant groups in the Netherlands, migrants from Turkey are extremely well organized; they have at their disposal a number of organizations that are connected in dense networks, and isolated organizations are rare (Fennema \& Tillie, 1999; Van Heelsum, Tillie, \& Fennema, 1999). Moreover, their organizational structures are more stable than those of other groups (Mügge, 2011a). Many organizations established in the 1970s and 1980s still exist. 
Figure 1Turkish population in the Netherlands, 1996-2011

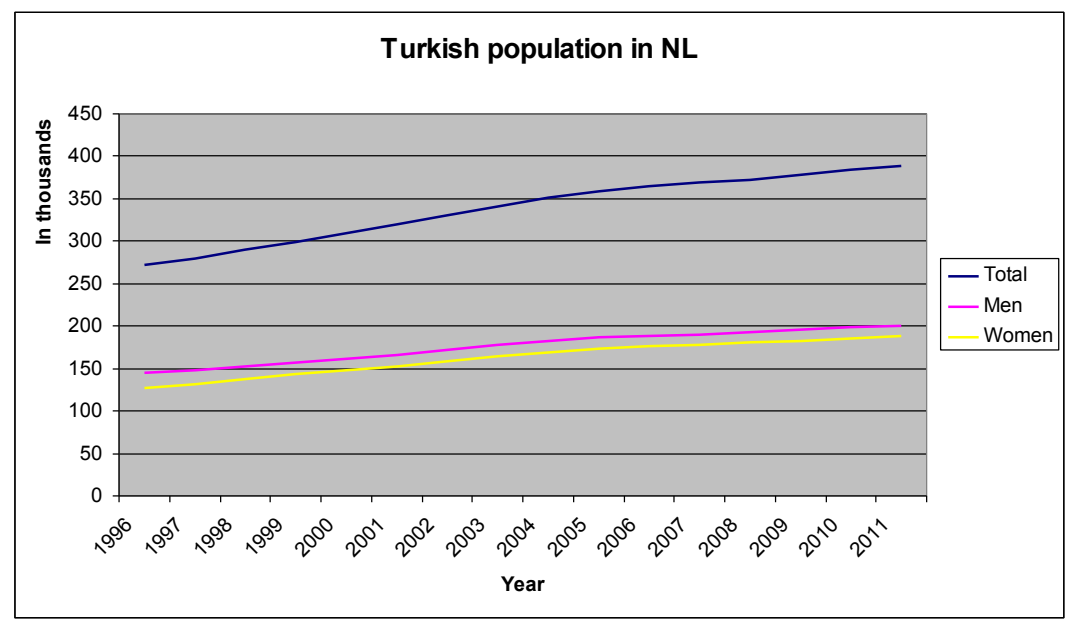

Source: Statline, Central Bureau for Statistics, http://statline.cbs.nl/statweb/

Between 1998 and 1999, the Institute for Migration and Ethnic Studies (IMES) of the University of Amsterdam found 1,125 organizations among Turks (including Kurds); only five per cent of those (61) focused on women. The study also collected more detailed data, including the names of the organizations, their addresses, and the names of their board members from the Dutch Chamber of Commerce. This information was available for 69 per cent (773) of the Turkish organizations. Using the original database, I established that only five per cent of those organizations (40 out of 773) were directed by women, and the grand majority of this subset specifically targeted women rather than the migrant group as a whole (see table 1).

Table 1 Female director and type of organization

\section{Type of organization}

\begin{tabular}{l|c} 
Women & 35 \\
\hline Religious & 2 \\
\hline Cultural & 2 \\
\hline Unknown & 1 \\
\hline Total & 40
\end{tabular}

The IMES analyzed Turkish organizational networks on the basis of the interlocking directorates of organizations: organizations were connected when one person was on the administrative board of two or more organizations. 
None of the organizations directed by a woman have a central position in the overall network of Turkish organizations (see figure 2 in Van Heelsum \& Tillie, p. 20). This means that the Turkish organizational network is almost completely male-dominated. That said, some organizations, such as the conservative Islamic Milli Görüş, organize activities specifically by and for women (for examples in Germany see Sökefeld, 2008). Mirroring the position of women in Islamist political movements in Turkey, this work has largely remained informal (White, 2002).

\section{Gendered Institutionalized Transnational Migrant Politics}

Using the IMES migrant organizational network as a starting point, I identified the key persons in migrant organizational networks who maintained institutionalized ties with political actors in Turkey or the diaspora. As noted earlier, the IMES network was constructed exclusively using interlocking directorates. Since administrative boards are seldom transnational in the sense that people from both the Netherlands and Turkey are formal members, additional research to expand and update the IMES network was needed. Between 2003-2005 new data was collected in the Netherlands and Turkey through interviews with organizational leaders and elites, through my own observations during activities, by reading newspaper articles, websites, organizations' brochures and reports. ${ }^{2}$ The new national and transnational ties I found were based on structural or sporadic cooperation, advice, memberships (among organizations and individuals), and kinship. During the interviews I asked interviewees to provide me with the contact details of homeland organizations with which they maintain ties (for full methodology see Mügge, 2010). Compared to the original data, the more qualitative approach only led to a very small increase in the number of organizations directed by women. Similarly, this additional work confirmed that the transnational ties maintained between migrant organizations in the Netherlands and collective actors in Turkey are by and large run by men.

Throughout my fieldwork, however, I had many conversations with women in both the Netherlands and Turkey. During two fieldtrips I spent a whole day in each at the side of a female member of a cultural organization involved in radical transnational politics, one radical leftist, and one Kurdish - both members of political parties which are illegal in Turkey. The conversations I had with them gave me an inside perspective on the role of women in their organizations. In both cases the women were very active, but did not belong to the administrative board. They had their own female networks within the organization and seemed no less radical than their male colleagues. Yet they had no formal authority. ${ }^{3}$ 
Figure 2 National and transnational ties of Turkish and Kurdish organizations

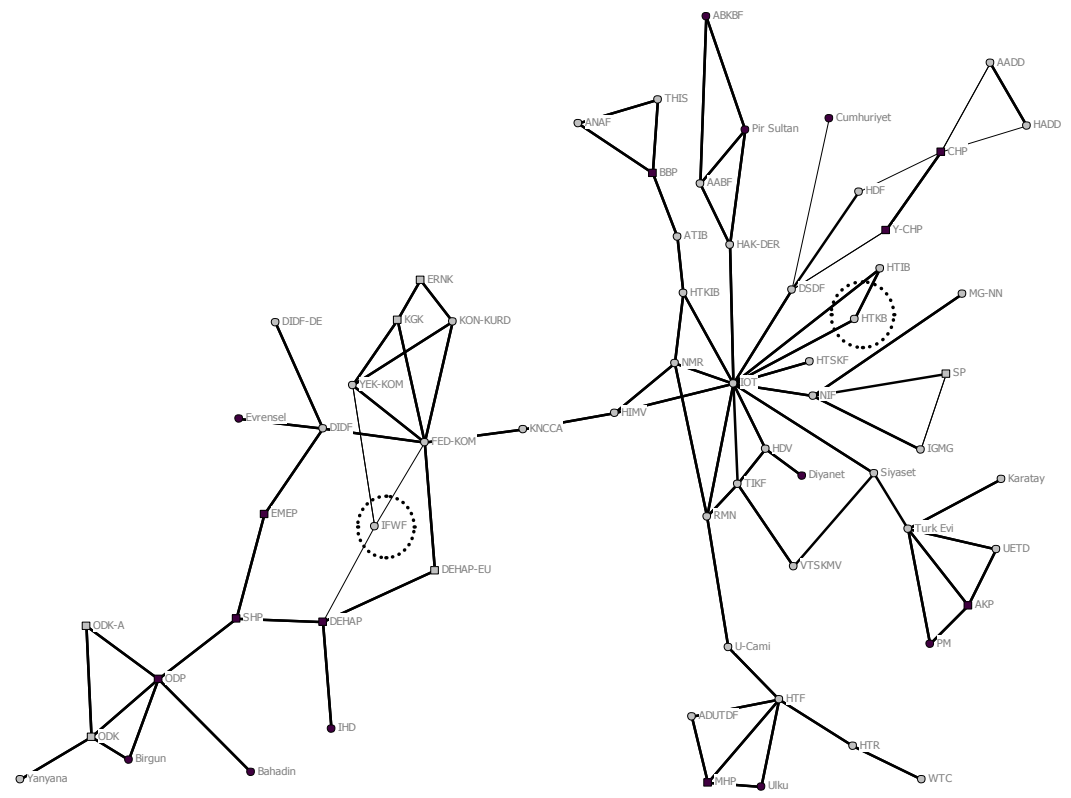

Square: Political party

Circle: Migrant organization/NGO

Black: Turkey

Grey: The Netherlands/Europe

Source: Mügge (2010, p. 104).

Figure 2 visualizes the national and transnational ties of the Turkish and Kurdish migrant organizations. Only two organizations directed by women in the largest two clusters of the Turkish and Kurdish organizational network have been transnationally active in the past or in the period under study: the Turkish Women's Federation in the Netherlands (HTKB) and the International Free Women's Foundation (IFWF) founded in 1977 and 2001, respectively (see the circled organizations in figure 2). In the 1970s HTKB united eight women's organizations. Although the Federation still exists, its transnational activities and ties have diminished over time. In the period under study (2003-2005), it maintained rather strong ties with other Turkish migrant organizations in the Netherlands, facilitated through membership in the Consultative Council of Turks in the Netherlands (IOT). The IOT was founded by the Dutch government in 1985 to represent the general interests of Turkish migrants in the Netherlands and provides the HTKB with a central position in the network (in figure 2 located in the cluster on the right). The HTKB is the only women's federation in the Council, since IOT member federations unite general organizations, often with separate women sections. The fact that Kurdish organizations are not members of the IOT explains 
why the cluster of Kurdish organizations and political parties is not attached to the centre. Instead, they form a separate sub-cluster of European Kurdish diaspora organizations and the Kurdish party DEHAP based in Turkey in which the IFWF is well embedded (in figure 2 left of the centre).

Both the transnational activities of the HTKB in the past and the IFWF in the period under study related to violence of the Turkish state against the left, Kurds, women or an intersection of these. The different eras in which both organizations were transnationally active - the HTKB in the 1970s and early 1980 s and the IFWF in the 2000s - have in common that state repression of their counterparts in Turkey reached its high point. Moreover, both organizations have been politicized by political refugees fleeing prosecution in Turkey. The following sub-sections describe their transnational ties and actions and analyse them in the context of the struggle for social justice of the leftist and the Kurdish movements in Turkey.

\section{Redistributive Social Justice Claims: Women and the Turkish Communist Party}

The HTKB was established as the women's organization of the Association of Turkish Workers (HTİB). HTIBB was founded in 1974 by a group of Turkish workers and refugees who had fled the Turkish military repression of 1971 (Can \& Can-Engin, 1997, p. 66). The federation was unambiguously Marxist and sympathized with the Turkish Communist Party (TKP), which had been illegal in Turkey for most of its existence. Initially, HTIB had a homelanddirected goal: to include Turkish workers in the Netherlands in the struggle of the Turkish people for a "democratic" Turkey. Between 1975 and 1979 HTİB became a national umbrella with different branches in the Netherlands. On a supranational level it established close ties with other Turkish organizations in European countries that supported the TKP. The influence of the TKP on HTIB increased when TKP leaders fled to the Netherlands and became members of the organization (Nell, 2008).

Initially the mission of the HTKB was to "emancipate" Turkish women in the Netherlands. Along with the political developments in Turkey and HTIB, it started to support the Progressive Women's Movement (IKD) in Turkey (see Santing, 1987). The IKD was founded in 1975 on the directive from the Turkish Communist Party (TKP) and was closed by constitutional law in 1979 , just before the coup d'état in 1980. By then it had grown to 30 branches across Turkey and had 50,000 members. One of İKD's founding members found refuge in Amsterdam and became involved with the HTKB. ${ }^{4}$ In exile she continued her political activities for the IKD and the TKP together with several leftist parties and trade unions which were outlawed in Turkey. The leadership of those leftist parties equally found a home in migrant organizations across Europe and started solidarity movements against the junta (Mügge, 2013). There was little, but some, clandestine contact with actors in Turkey. “our friends were under police interrogation, we didn't like 
to write letters because they could be used against them."5 (In the mid-1980s, when the political conflicts in Turkey cooled somewhat, HTKB activities gradually shifted to the integration of Turkish women in the Netherlands. They closely cooperated with leading organizations and persons in the Dutch feminist movement and with female leftist politicians.

This experience inspired a HTKB board member and IKND founder to support the initiative to establish the Association for the Support and Training of Women Candidates (KA-DER) upon her return to Turkey in the 1990s. ${ }^{6}$ KA-DER unites members of all major political parties and aims to strengthen the position of women in politics at all levels of decision-making and to fight discrimination against women in politics (Tekeli, 2010, p. 119). Although KA-DER maintains some contact with individual Turkish feminists in European countries, often former political exiles, there are no structural ties with Turkish migrant organizations. ${ }^{7}$

Transnational ties with the HTKB served for IKKD activists as a temporary residence to continue their class struggle. When the Turkish communist movement fell apart in the mid-1980s, those ties dissolved. Former İKD exiles returned to Turkey to support the women's movement there, whereas the HTKB intensified its endeavours to stimulate the emancipation of migrant women in the Netherlands.

The organizational structure of the HTKB and HTIBB was copied from the IKD and TKP in Turkey. As a consequence of the military coups of 1971 and 1980, HTKB and HTIB became interwoven with the IKD and the TKP and replaced some of its functions. IKDD and the TKP cadre in exile entered the board of administration of HTKB and HTIB. The IKDD was established in response to a top-down initiative to strengthen the TKP with a women's organization. The TKP leadership considered the IKDD "a rich source for the TKP of young woman communists who [had] been tested in action" (as cited in Ozcurumez \& Cengiz, 2011, p. 26). As a former IKKD member put it, “The membership period was considered as a process consisting of several stages leading to party membership" (as cited in Ozcurumez \& Cengiz, 2011, p. 26).

The IKD did not directly address gender equality, but associated "its raison d'être with the ideological conviction of class identity and struggle" (Ozcurumez \& Cengiz, 2011, p. 24-25). Publications originating from Moscow, rather than feminist writing from Western countries, were the main inspiration for İKD members: "We found solutions to everything in those publications" (as cited in Ozcurumez \& Cengiz, 2011, p. 27). The aim of the organization in its statutes was described as:

All women, but first of all working class women, should be able to use fully their legal rights in the family and the society. The priority of the organization is therefore rearranging the laws that harm women's rights and freedom [and] defending women's labor in accordance with equal pay principle in the factories, fields, bureaus. (as cited in Ozcurumez \& Cengiz, 2011, p. 25)

İKD references to everyday women's problems were limited to demanding kindergartens in factories. Such demands have led to accusations of 
"feminism" and weakening the socialist front, something İKD members naturally tried to avoid (as cited in Ozcurumez \& Cengiz, 2011). Within the ideological pressure of the orthodox left, feminism was branded a bourgeois deviation (Sirman, 1989). The "woman question" was

...simply an introductionary [sic] question intended to recruit women to join the communist cause and become activists. [IKD's] existence is related to a political organization with massive political objectives; the particular objective of arriving at solutions to women's problems is, at best, subsidiary. (Ozcurumez \& Cengiz, 2011, p. 26)

The İKD was heavily criticized by second wave feminists "for subordinating women's issues to the cause of socialism and the labour movement" (Tekeli 1990 cited by Ozcurumez \& Cengiz, 2011, p. 24). In the 1980s, however, women who had been active in leftist political organizations such as IKD became the key actors of the independent women's movement. They started to criticize the male domination in the leftist movement. In small consciousnessraising groups they paved the way for the second feminist wave in Turkey (Al-Rebholz, 2010; Çubukçu, 2004).

First-wave feminism, claiming the extension of citizens' rights for women, had ended already in 1935, with the official closure of the Turkish Women's Organization. It was argued by the state that with the newly founded Turkish Republic in 1923 legal equality between all citizens, irrespective of gender, had been achieved (Berktay, 2004). The new civil code (1926), based on Swiss law, replaced Islamic law and polygamy was officially outlawed (Mango, 2002, p. 438). Furthermore, women were granted suffrage rights and education became compulsory for both girls and boys (Pusch, 2000, p. 483). The downside of those changes was that this "state feminism" created the myth that Turkish women had full equal rights with men; consequently, there was no more need for women's organizations: "Kemalist [state] ideology was the only option available to women" (Tekeli, 1992, p. 139).

Surprisingly, the second feminist wave evolved just after the 1980 coup when all political parties were closed except those few founded and controlled by the military; many political leaders, labour unions and political organizations were banned from politics (Diner \& Toktaş, 2010, p. 45). Violent confrontations between radical leftist and right-wing groups that had led to political instability served as the main justification for the military's intervention in politics, and spawned a "depoliticized" environment in the 1980s (Diner \& Toktaş, 2010; also see Pope \& Pope, 1997). It was at this moment, when civil society was severely restricted, that an independent women's movement flourished. Some scholars have argued that this momentum in 1980 was partly due to the opportunities presented by the imprisonment of many male political activist and leaders (Diner \& Toktaş, 2010, p. 45).

In the post-coup period women's organizations defined themselves as "feminist" for the first time (as cited in Ozcurumez \& Cengiz, 2011). The number of women's organizations rose from ten in the late 1970s to 64 in 
the 1980s and early 1990s (Diner \& Toktaş, 2010, p. 47). Second-wave feminists fought against the patriarchal gender roles and relations "so that the rights granted by law could be put into practice in social, cultural, political and economic domains" (Çubukçu, 2004, p. 56). In addition to the leftist feminist groups, Islamic activists, and secular nationalists, also known as Kemalists, started to organize. Whereas Kemalist women represent the officially dominant ideology of the state (Arat, 2010; Arat-Koç, 2007), the leftist or "new" feminists and Islamic women put forward counter ideologies (Sakaranaho, 2008, p. 50-51).

The İKD and the HTKB clearly did not challenge patriarchy; they operated between the first and second feminist waves in Turkey. It was a period in which the "state feminism" of the early republican period largely turned into a "party feminism" (Eslen-Ziya \& Korkut, 2010, p. 320). The claims of party feminists for social justice can be characterized as "redistributive" in its narrow sense, encompassing only class-centred orientations in line with the dominant ideologies of the Cold War period. Their remedy for injustice is economic restructuring (Fraser, 1996, p. 7).

\section{The Politics of Recognition and Redistribution: the Kurdish Struggle}

In contrast to the HTKB, the IFWF does not present itself as a migrant organization but as an international women's foundation fully committed to supporting social and humanitarian projects for women and children in the Middle East. The foundation is carried by women "who personally experienced the devastating effects of war and men's violence," and it "struggles against all forms of militarism, fascism, nationalism and discrimination ... by taking peaceful solutions of social questions as its basis." Kurdish women in Turkey and female Kurdish refugees in Europe, but simultaneously aim to bridge human rights with the Kurdish question. ${ }^{9}$ IFWF particularly opposes the policy of assimilation and discrimination against the Kurdish people.

The organization cooperates ad-hoc with international women's organizations as well as with Kurdish organizations in the diaspora that sympathize with the PKK, women's organizations in Turkey and the Kurdish political party (which was DEHAP at the time of my research in 2004). For instance, they provided support to a feminist organization with a large Kurdish membership, Katagi, in Istanbul. ${ }^{10}$ Like IFWF, they consider themselves "anti-patriarchal," "anti-militarist," and continuously address the salience of the Kurdish question by sending press releases to leftist parties, syndicates and other relevant actors in civil society in Turkey.

IFWF's broad cooperation came to the fore in supporting the protests against the rape and torture of Gülbahar Gündüz, who was an executive member of the Women's Section of the Kurdish party DEHAP in Istanbul. Gündüz was abducted from the street in June 2003, possibly by policemen. She was interrogated, sexually abused and tortured: "The men told her that 
she should not be leading political activities because she is a woman and that this would be a lesson to her" (cf. FIDH, 2003; KHRP, 2003). ${ }^{11}$ The Gündüz case was broadly interpreted as a frontal attack against the peace struggle of Kurdish women. It received ample attention on Kurdish websites, hosted from both Europe and Turkey itself. ${ }^{12}$ Following the Gündüz case an IFWF delegation was invited to the women's branch of DEHAP in Istanbul. DEHAP informed the delegation about Gündüz and other cases of female members of the party who had been tortured and raped. ${ }^{13}$ IFWF called on women's institutions "to express their solidarity with Gulbahar Gündüz and to show their protest against the practices of the Turkish security forces." 14

The objectives of IFWF resemble the activities of the Kurdish women's movement which evolved out of the Kurdish nationalist movement, fuelled by the establishment of the Kurdistan Worker's Party (PKK) in 1977. The PKK initially was Marxist-Leninist oriented. It opposed "Turkish imperialism," which, it argued, was prevalent in "Turkish Kurdistan" (Güney, 2002, p. 123). The organization held Kurdish landlords primarily responsible for collaborating with the Turkish ruling classes (Taspinar, 2005, p. 94). The PKK strategy was to mobilize destitute social classes, the uprooted smalltown youth and poor peasants against these landlords and traditional chiefs cooperating with the central government in Ankara (Taspinar, 2005, p. 95). For the PKK, the intensity of Kurdish national feeling was accentuated by the loss of spoken Kurdish among its founding members (McDowall, 1996, p. 419).

The 1980 coup has been crucial for Kurdish women's awareness; the detention of tens of thousands of Kurdish men forced women to take a more active role in society and politics. Kurdish women's groups started to pinpoint the multiple "exploitation" that they experienced because of their gender and ethnicity. First, they criticized the patriarchal system dominant in Kurdish culture and endorsed by the nationalist movement. Second, they felt oppressed through the "imperialist" system that the central state imposed on Kurdish people. At the same time, these women condemned mainstream and state feminists for being "ethnocentric" and exclusionary of other identities (Diner \& Toktaş, 2010, pp. 41, 47). Gradually, Kurdish women became active in political parties like DEHAP and gained public visibility in a number of organizations (Diner \& Toktaş, 2010, p. 49; Yüksel, 2006).

The 1980s and 1990s witnessed the rise of Kurdish nationalism and an increasing militaristic response by the Turkish state (Ilkkaracan, 2001). The leader of the PKK, Abdullah Öcalan, began to insist that the Kurdish movement's "basic responsibility [was] to ... liberate women" (as cited in Marcus, 2007, p. 173). He stressed that the PKK's revolutionary fight would be impossible without the presence of women. Among PKK members, however, it was frequently argued that the time was not right for women's rights and that priority should be given to national self-determination (Kirişçi, 2009). According to Marcus, (2007) it is unclear whether Öcalan truly believed in gender equality, "but he certainly understood that he could gain a powerful ally if he defended their rights" (p. 173). It seemed to work: 
women comprised a third of the PKK's armed forces by 1993. But joining the PKK may simply have been the better of two options. Many young women saw the PKK as an acceptable form of escape form their daily lives:

\begin{abstract}
A Kurdish father could block his daughter from working ... from going to high school ... but it was not easy to criticize her decision to fight for Kurdish freedom. Doing so could raise questions about a family's real loyalties, which in turn could put the family at odds with the PKK.... Such comments could raise questions inside the PKK about the loyalties of the girl who had joined, possibly endangering her life. Besides, the PKK was said to protect a girl's virginity with the same zeal as her family, something that helped shore up support for the PKK. (Marcus, 2007, p. 174)
\end{abstract}

The explicit attention to gender equality was largely part of a strategy to strengthen the movement, which very much resembles the working style of the Turkish Communist Party in the 1970s.

Since the early 1990s, Kurdish political parties have taken part in parliamentary elections under different names, since all of them at one point or another had been closed by constitutional courts. In the period under study HADEP had just closed and its work was continued by DEHAP. ${ }^{15}$ The parties have had and still have active women's branches and women on the executive level. Indeed, one of the heroines of the Kurdish struggle is a woman, Leyla Zana.

It could be argued that the aims and activities of the Kurdish organization IFWF, as well as their transnational ties with pro-Kurdish women's organizations and parties, are a part of the third feminist wave in Turkey. Similar to third-wave feminisms in Western countries, third-wave feminism in Turkey is characterized by its religious and ethnic diversity (Kerestecioğlu, 2004). However, in contrast to deconstructive feminists or queer activists, Kurdish women do not challenge the essentialism of traditional identity politics.

The redistributive elements of the social justice conception of Kurdish women are not surprising since the Kurdish national movement has its origins in the leftist movement of the 1970s in Turkey (White, 2000). Kurdish women emphasize multiple exploitation on the basis of gender and ethnicity. Therefore, their conception of social justice contains elements of both the politics of redistribution as well as of the politics of recognition. Following Fraser, those are "dimensions of justice that can cut across all social movements" (emphasis original Fraser, 1996, p. 6). Such a blurred conception of social justice is clearly reflected in the transnational activism of the IFWF.

\title{
Conclusion
}

This article has analyzed the conceptions of social justice of women active in Kurdish and Turkish transnational migrant politics in a period of roughly 
20 years. The historical perspective has allowed us to study whether the shift in conceptions of social justice from the politics of redistribution in the Cold War period to the politics of recognition in a neo-liberal context observed among traditional social movements also applies to transnational migrant politics of women. Inspired by Fraser (1996), this article has asked to what extent both dimensions of social justice are mutually exclusive or can be combined.

So far, gender outside typical female spaces has been understudied in research on migrant transnationalism. A gendered analysis shows that transnational politics is almost completely male dominated. Women's role in transnational politics is mostly invisible and private. In a period of roughly 20 years, only two organizations directed by women had a central position in the network of transnational politics: the leftist women's organization HTKB and the Kurdish women's organization IFWF. In both transnational programmes, "the woman question" has clearly been subordinated to a broader political programme, in these cases Marxism and Kurdish nationalism. Additionally, women seem to acquire a more central role in transnational politics when political movements in the homeland are outlawed and many of their male members are detained. Their support, either to the general movement or to the women in the homeland, then becomes vital for the organization. In the case of HTKB, its transnational orientation diminished when the Turkish communist party (TKP) fell apart and the political climate in Turkey cooled. In contrast, the IFWF was created to support Kurdish women in exile or in Turkey who faced oppression by the Turkish state due to their own political activities and convictions or those of their male relatives. Due to this "supportive" working style, the transnational politics of migrant women did not develop its own conceptions of social justice, but adopted the ones of male-dominated political organizations. The transnational ties of HTKB and IFWF mirrored the ideologies and activities of the leftist women's movement in the 1980s and the Kurdish women's movement in the 1990s and 2000s. Questions on gender equality, therefore, have been addressed in rather instrumental ways to strengthen the homeland party. In these cases, gender hierarchies from the homeland were not challenged, but rather reproduced. In that sense, migrant women do not really "go public" in transnational politics.

The conception of social justice in transnational activities and ties observed during the Cold War period fit the narrow definition of the "politics of redistribution," as its remedy for injustice is economic restructuring. In the neo-liberal context of the 1990s and 2000s, the Kurdish movement combines both elements of justice of the politics of redistribution and recognition. Emphasis on the first form of social justice is an obvious result of the Marxist heritage of the Kurdish movement. While elements of the latter are defined more narrowly, Kurds do not aim for the deconstruction of categories, as queer activists or migrants might do. Their struggle is based on recognition of the category "Kurd" as a distinct ethnicity.

The organizations in the sample studied were mostly led by first-generation migrants. In those organizations women's roles were predominantly private. 
Over the past decade, second- and third- generation Turks and Kurds have gradually entered the boards of administration of mainstream organizations or established their own alternatives. The question is how this generational change will play out for the extent to which women get a more public role in migrant politics or the mainstream politics of the receiving society. Unless new conflicts evolve in the homeland, or old ones regain intensity, it is unlikely that they will continue transnational political activities; instead, their struggle for social justice will focus on discrimination in the receiving societies.

\section{Acknowledgements}

An earlier and shortened version of this article has been presented at the conference "Men and Masculinities Moving on Again! Transnationalising Flows, Technologies, Institutions, Theory," Linköping (2011) and is published as a conference proceeding (Mügge 2011b). I thank Anja van Heelsum for sharing the database on Turkish organizations, the Studies in Social Justice reviewers for their constructive feedback and the Harvard Centre for European Studies for hosting me as a visiting scholar in spring 2012.

\section{Notes}

Statline, Central Bureau for Statistics, http://statline.cbs.nl/statweb/.

This study was part of a $\mathrm{PhD}$ project on transnational politics of Surinamese, Kurds and Turks in the Netherlands, completed at the Institute for Migration and Ethnic Studies at the University of Amsterdam in December 2008.

3 It is noteworthy that the migrant organizations figure 1 are for the great majority established and directed by the first generation. By the late 1990s second generation youngsters started to become part or administrative boards, and in leftist organizations I also observed females. It is thus possible that today the picture looks different.

4 Interview with a founding member of IKD and former HTKB member, Istanbul, 19 November, 2005.

Ibid.

Ibid.

Interview with the director of KA-DER, Istanbul, 1 August 2003.

For the full mission statement see http://www.freewomensfoundation.org

Interview with IFWF board member, Amsterdam, 27 October 2004.

Interview with a volunteer of Katagi, Istanbul, July 15, 2003.

11 See http://www.omct.org/violence-against-women/urgent-interventions/ turkey/2003/10/d16566/, accessed 10 May 2011.

12 See for instance http://www.nadir.org/nadir/initiativ/isku/, http://www.kwahk.org/ articles.asp?id=18, http://ydicagri.org/ingilizce_sayfalar/gulbahar.html, http://www. kurdmedia.com/article.aspx?id=9213, all accessed 10 May 2011.

13 Interview with a board member and member of DEHAP Istanbul, Istanbul, 8 August 2003.

14 See http://www.freewomensfoundation.org/english/news/Press\%20Statements/ pressreleases\%20IFWF\%2001.htm and http://www.enawa.org/scripts/wwwopac.exe ?database $=$ brief $\&$ isutf $8=1 \& \% 250=100383$, accessed 10 May 2011 .

15 At the time of writing the name of the party is the BDP. 


\section{References}

Al-Ali, N. (2002). Gender relations, transnational ties and rituals among Bosnian refugees. Global Networks, 2(3), 249-262.

Al-Rebholz, A. (2010). Regieren der Geschlechterverhältnisse im Wandel: Transnationale Strategien der Frauenbewegungen in der Türkei. Femina Politica, 2.

Aliefendioğlu, H. (2004). Transnational space between women's NGOs in Germany and Turkey: Current situation and future expectations. In T. Faist \& E. Özveren (Eds.), Transnational social spaces. agents, networks and institutions (pp. 59-90). Aldershot: Ashgate

Arat-Koç, S. (2007). (Some) Turkish transnationalism(s) in an age of a capitalist globalisation and empire: "White Turk" discourse, the new geopolitics and implications for feminist transnationalism. Journal of Middle Eastern Women's Studies, 3(1), 35-57.

Arat, Y. (2010). Religion, politics and gender equality in Turkey: Implications of a democratic paradox? Third World Quaterly, 31(6), 869-884.

Bakker, R., Vervloet, L., \& Gailly, A. (2002). Geschiedenis van Turkije. Amsterdam: Bulaaq.

Bauböck, R., \& Faist, T. (Eds.). (2010). Diaspora and transnationalism. Concepts, theories and methods. Amsterdam: IMISCOE Research Series Amsterdam University Press

Ben-Rafael, E., Sternberg, Y., Liwerant, J. B., \& Gorny, Y. (Eds.). (2009). Transnationalism diasporas and the advent of a new (dis)order Leiden Brill.

Berktay, F. (2004). Introduction: Building bridges to raise mutual understanding and collaboration. In F. Berktay, I. O. Kerstecioglu, S. U. Cubukcu \& Z. K. Forsman (Eds.), The position of women in Turkey and the European Union: Achievements, problems, prospects (pp. 13-32). Istanbul: KA-DER Press.

Brand, L. (2006). Citizens abroad: Emigration and the state in the Middle East and North Africa: Cambridge University Press.

Can, M., \& Can-Engin, H. (1997). De zwarte tulp. De positie van Turken in Nederland. Utrecht: Uitgeverij Jan van Arkel.

Çubukçu, S. U. (2004). Post-1980s Women's movement in Turkey: A challenge to patriarchy. In F. Berktay, I. Ö. Kerestecioğlu, S. U. Çubukçu \& Z. K. Forsman (Eds.), The position of women in Turkey and in the European Union: Achievements, problems, prospects (pp. 35-54). Istanbul KA-DER Press

De Tona, C., \& Lentin, R. (2011). Networking sisterhood, from the informal to the global: AkiDwa, the African and Migrant Women's Network, Ireland. Global Networks, 11(2), 242261.

Diner, C., \& Toktaş, Ş. (2010). Waves of feminism in Turkey: Kemalist, Islamist and Kurdish women's movements in an era of globalization. Journal of Balkan and Near Eastern Studies, 12(1), 41-57.

Eslen-Ziya, H., \& Korkut, U. (2010). Political religion and politicized women in Turkey: Hegemonic republicanism revisited. Totalitarian movements and political religions, 11(3-4), 311-326.

Esman, M. J. (2009). Diasporas in the contemporary world. Cambridge: Polity Press.

Fennema, M., \& Tillie, J. (1999). Political participation and trust in Amsterdam: Civic communities and ethnic networks. Journal of Ethnic and Migration Studies, 25(4), 703-726.

Fibbi, R., \& D'Amato, G. (2008). Transnationalisme des migrants en Europe: une preuve par les faits. Revue européenne des migrations internationales, 24(2), 7-22.

FIDH. (2003). Turkey human rights in the Kurdish Southeast: Alarming situation despite extensive legal reforms Paris: The International Organization for Human Rights.

Fouron, G., \& Glick Schiller, N. (2001). All in the family: Gender, transnational migration, and the Nation-State. Identities: Global Studies in Culture and Power, 7(4), 539 - 582.

Fraser, N. (1996). Social justice in the age of identity politics: Redistribution, recognition and participation. Stanford: The Tanner Lectures on Human Values. Delivered at Stanford University April 30-May 2.

Güney, A. (2002). The People's Democracy Party. In B. Rubin \& M. Heper (Eds.), Political parties in Turkey (pp. 122-137). London: CASS.

Hagan, J. M. (1998). Social networks, gender and immgrant incorporation: Resources and 
constraints. American Sociological Review, 63(1), 55-67.

Ilkkaracan, P. (2001). Islam and women's sexuality. A research report from Turkey. In P. B. Jung, M. E. Hunt \& R. Balakrishnan (Eds.), Good sex. feminist perspectives from the world's religions (pp. 61-70). New Brunswick: Rutgers University Press.

Itzigsohn, J., \& Giorguli-Saucedo, S. (2005). Incorporation, transnationalism, and gender: Immigrant incorporation and transnational participation as gendered process. International Migration Review, 39(4), 895-920.

Kerestecioğlu, I. Ö. (2004). Women's movement in the 1990s: Demand for democracy and equality. In F. Berktay, I. Ö. Kerestecioğlu, S. U. Çubukçu \& Z. K. Forsman (Eds.), The position of women in Turkey and in the European Union: Achievements, problems, prospects (pp. 75-98). Istanbul: KA-DER Press.

Khagram, S., \& Levitt, P. (Eds.). (2008). The transnational studies reader. Intersections \& innovations. New York: Routledge.

KHRP. (2003). Trial observation report. Turkey's shame: Sexual violence without redress - The plight of Kurdish women. London: Kurdish Human Rights Project.

Kirişçi, K. (2009). A "three-way approach" to incorporating muslim immigrants in the EU: A Turkish perspective. International Journal on Multicultural Societies, 11(2), 119-135.

Levitt, P., \& Jaworsky, B. N. (2007). Transnational migration studies: Past developments and future trends. Annual Review of Sociology, 33, 129-156.

Mahler, S. (1998). Theoretical and empirical contributions. Toward a research agenda for transnationalism. In M. P. Smith \& L. E. Guarnizo (Eds.), Transnationalism from Below (pp. 64-102). New Brunswick: Transaction Publishers.

Mango, A. (2002). Atatürk. The biography of the founder of Modern Turkey. Woodstock: The Overlook Press.

Marcus, A. (2007). Blood and belief. The PKK and the Kurdish fight for independence. New York: New York University Press.

Martiniello, M., \& Lafleur, J.-M. (2008). Towards a transatlantic dialogue in the study of immigrant political transnationalism. Ethnic and Racial Studies, 31(4), 645 - 663.

McDowall, D. (1996). A modern history of the Kurds. London: I.B.Tauris.

Menjívar, C. (2000). Fragmented ties. Salvadoran immigrant networks in America. Berkeley: University of California Press.

Moors, J. A., Van den Reek Vermeulen, E., \& Siesling, M. (2009). Voedingsbodem voor radicalisering bij kleine etnische groepen in Nederland. Een verkennend onderzoek in de Somalische, Pakistaanse, Koerdische en Molukse gemeenschappen. Tilburg: IVA beleidsonderzoek en advies.

Mügge, L. (2010). Beyond Dutch borders. Transnational politics among postcolonial migrants, guest workers and the second generation. Amsterdam: IMISCOE Amsterdam University Press (Research Series).

Mügge, L. (2011a). Diversity in transnationalism: Surinamese organizational networks. International Migration 49(3): 52-75.

Mügge, L. (2011b). The male domination of transnational migrant politics. In A. Biricik \& J. Hearn (Eds.), Proceedings from GEXcel Theme 9: Gendered Sexualed Transnationalisations, Deconstructing the Dominant: Transforming men, "centres" and knowledge/policy/practice, Spring 2011 Vol. 15. GEXcel Work in Progress Report (pp. 41-49). Linköping: Institute of Thematic Gender Studies.

Mügge, L. (2013). Brussels Calling. The European Organization of Migrants from Turkey. In Z. Sezgin \& D. Halm (Eds.) Cross-border migrant organizations - Rethinking national integration policy (152-172). New York: ECPR Series Routledge.

Naples, N. A., \& Desai, M. (Eds.). (2002). Women's activism and globalisation. linking local struggles and transnational politics. New York: Routledge.

Nell, L. M. (2008). The long shadow of homeland politics: Understanding the evolution of the Turkish radical left in the Netherlands. Revue Européenne des Migrations Internationales (REMI), 24(2):121-145.

Ögelman, N. (2003). Documenting and explaining the persistence of homeland politics among Germany's Turks. International Migration Review, 37(1), 163-193.

Østergaard-Nielsen, E. (2003). Transnational Politics. Turks and Kurds in Germany. London/ New York: Routledge.

Ozcurumez, S., \& Cengiz, F. S. (2011). On resilience and response beyond value change: 
Transformation of women's movement in post-1980 Turkey. Women's Studies International Forum, 34, 20-30.

Pope, N., \& Pope, H. (1997). Turkey unveiled. Atatürk and after. London: John Murray.

Pries, L. (Ed.). (2008). Rethinking transnationalism. The meso-link of organizations. London: Routledge.

Pusch, B. (2000). Stepping into the public sphere: The rise of Islamist and religious-conservative women's non-governmental organizations. In S. Yerasimos, G. Seufert \& K. Vorhoff (Eds.), Civil Society in the Grip of Nationalism (pp. 475-506). Istanbul: Orient-Institut.

Sakaranaho, T. (2008). "Equal but different:" Women in Turkey from the Islamic point of view. In A. Kynsilehto (Ed.), Islamic feminism: Current perspectives (pp. 47-56). Tampere: Tampere Peace Research Institute.

Salih, R. (2007). Troubles and promises of transnational women's networking across the Meditarranean. In S. Macchi \& E. Zambelli (Eds.), Women's Networking Across Borders. Cooperation, Diaspora and Migrations between Italy and the Middle East (pp. 45-65). Rome: CIRPS SPED.

Santing, F. (1987). Die vrouw, dat ben ik. Over het leven van Turkse vrouwen. Rotterdam: Stichting Samen Leven Samen Wonen.

Schapendonk-Maas, H. (2000). Jonge tweede generatie allochtonen. Index, 9(October), 26-27.

Schrover, M., \& Vermeulen, F. (2005). Immigrant organizations. Introduction. Journal of Ethnic and Migration Studies, 31(5), 823-832.

Shain, Y. (1999). Marketing the American greed. Diasporas in the U.S. and their homelands. Cambridge: Cambridge University Press.

Sheffer, G. (2003). Diaspora Politics. At home abroad. Cambridge: Cambridge University Press.

Sirman, N. (1989). Turkish Feminism: A Short History. New Perspectives on Turkey, 3, 1-34.

Sökefeld, M. (2008). Struggling for recognition. The Alevi movement in Germany in transnational space. New York: Berghahn Books.

Taspinar, O. (2005). Kurdish nationalism and political Islam in Turkey. Kemalist identity in transition. London: Routledge.

Tekeli, S. (1992). Europe, European feminism and women in Turkey. Women's Studies International Forum, 15(1), 139-143.

Tekeli, S. (2010). The Turkish women's movement: A brief history of success. Quaderns de la Mediterania, 14, 119-123.

Van Bruinessen, M. (1999, June 17). Eerder verdeeld dan verenigd. NRC webpaginas http:// www.nrc.nl/W2/Lab/Profiel/Koerden/identiteit.html.

Van Heelsum, A. (2002). The relationship between political participation and civic community of migrants in the Netherlands. JIMI/RIMI, 3(2), 179-200.

Van Heelsum, A., Tillie, J., \& Fennema, M. (1999). Turkse organisaties in Nederland. Een netwerkanalyse. Amsterdam: Spinhuis.

Vermeulen, F. (2006). The immigrant organising process. The emergence and persistence of Turkish immigrant organizations in Amsterdam and Berlin and Surinamese organizations in Amsterdam, 1960-2000. Amsterdam: Amsterdam University Press.

Vertovec, S. (2009). Transnationalism. New York: Routledge.

White, J. B. (2002). Islamist mobilization in Turkey. A study in vernacular politics. Washington: University of Washington Press.

White, P. (2000). Primitive rebels or revolutionary modernizers? The Kurdish National Movement in Turkey. London: Zed Books.

Yüksel, M. (2006). The encounter of Kurdish women with nationalism in Turkey. Middle Eastern Studies, 42(5), 777-802.

Yurdakul, G. (2009). From guest workers into Muslims. The transformation of Turkish immigrant associations in Germany. Newcastle: Cambridge Scholars Publishing. 